


\title{
RECUPERAÇÃO SOCIOAMBIENTAL URBANA: O MORRO DAS PEDRAS E O CÓRREGO DO PASTINHO'
}

\author{
URBAN ENVIRONMENTAL RECOVERY: \\ MORRO DAS PEDRAS AND PASTINHO STREAM
}

Danilo de Carvalho Botelho Almeida²

Margarete Maria de Araújo Silva ${ }^{3}$

\begin{abstract}
Resumo
O artigo apresenta o trabalho desenvolvido pelo Escritório de Integração da PUC Minas junto à Secretaria de Defesa Social do Estado de Minas Gerais, tendo como área de atuação a microbacia do Córrego do Pastinho. A presença do córrego em leito natural conferia à área um caráter singular: a possibilidade de investigação de novo padrão de intervenção baseada na relação harmoniosa entre gente e água em meio urbano. A experiência iniciou-se a partir da proposta de adequação e aplicação da metodologia CPTED (Prevenção do Crime através do Desenho Ambiental) em áreas caracterizadas por altos índices de criminalidade e violência urbanas, mais especificamente no Aglomerado Morro das Pedras, em Belo Horizonte.
\end{abstract}

Palavras-chave: Violência e criminalidade urbanas; Espaços urbanos seguros; Água em meio urbano; Autogestão.

\begin{abstract}
This article presents the work carried out by the Escritório de Integração da PUC Minas (PUC Minas Integration Office) with the Department of Social Defense of Minas Gerais State in the micro-basin of Pastinho Stream. The presence of the stream natural bed confers a singular quality to the area: the possibility of research into a new intervention pattern based on the harmonious relationship between people and water in an urban environment. The experience began with the proposition of suitability and application of the CPTED - Crime Prevention through Environmental Design - methodology in areas characterized by high rates of criminality and urban violence, specifically in Aglomerado Morro das Pedras, in Belo Horizonte.
\end{abstract}

Key words: Urban violence and criminality; Safe urban spaces; Water in urban environments; Self-management. 